\title{
Het MAB vóór 50 jaar
}

juli/augustus 1933

In het vervolgartikel met de Wirtschaftsprüfer als onderwerp wordt thans de vraag behandeld of deze, naar Duitse opvattingen, tegelijkertijd Wirtschaftsberater kan zijn. Het is een omvangrijk artikel waarin veel auteurs worden aangehaald. Alle argumenten pro en contra, zoals die ook nu nog onder ons leven komen wel aan bod. Raadgevende ingenieurs, die ook in de Hauptstelle vertegenwoordigd zijn, zijn ook wel van mening dat de wetgever onder Wirtschaftsprüfung iets geheel anders heeft bedoeld en wat zij liever Betriebsprüfung zouden willen noemen. De reactie daarop is dat zij eerst een betekenis opdringen aan de Wirtschaftsprüfung welke niemand ooit bedoeld heeft daaraan te geven, om dan vervolgens triomfantelijk te beweren dat het absurd is een zo sterk technisch geörienteerd onderzoek te laten verrichten door een deskundige, die, volgens hen alleen maar in staat is het onderdeel der Buch- und Bilanzprüfung te verzorgen.

De New-York Stock Exchange maakt sinds april 1932 al overeenkomsten met iedere maatschappij welke een notering van haar waarden op de beurs aanvraagt. Daarbij werd de, bij de stukken te voegen verklaring van een public-accountant met name vereist. Vanaf 1 juli 1933 worden de eisen weer iets uitgebreid. De commentator Van Rietschoten merkt op dat uit een en ander de waardering voor het werk van de public-accountant als vertrouwensman van het publiek sterk spreekt. Hij stelt de vraag of het bestuur van de Amsterdamse effectenbeurs ook niet van een dergelijke waardering zou kunnen doen blijken. Daarmede zou de weg naar een wettelijke controle op de financiële verslaglegging in Nederland aanzienlijk vergemakkelijkt worden.

Hoewel de rubriek 'Efficiëntie' door twee redacteuren wordt verzorgd komt deze vrijwel nooit aan bod. In het huidige nummer is daarop een uitzondering gemaakt: in vier kolommen worden vijf onderwerpen behandeld waarvan ik er drie wil noemen: 'Zo is er thans een machine die zien kan; als zodanig kan men een toestel betitelen, dat, als een der laatste toepassingen der steeds meer burgerrecht verkrijgende photocel, aangewend wordt bij het verpakken van cigaretten'. Het artikel wordt afgesloten met de overpeinzing dat, moge het belang bij de verpakking van cigaretten er een van ondergeschikte aard zijn en vooral uit het oogpunt van ordelijkheid en 
reclame worden nagestreefd, het geen betoog behoeft dat het vraagstuk in andere gevallen van meer wezenlijk belang zal zijn. Het volgende onderwerp dat stellig de belangstelling zal hebben getrokken betrof de mogelijkheid van de vermindering van magazijnvoorraden door het uitoefenen van voorraadcontrole. $\mathrm{Na}$ een uiteenzetting waarom dit een belangrijk vraagstuk is wordt een procedure beschreven hoe met behulp van ponskaarten controle kan worden uitgeoefend op magazijnvoorraden, op aanschaffingen, op de vaststelling van maximum- en minimumvoorraden en op de evenredigheid tussen aanschaffingen en afgeleverd product. Als laatste punt vermeld ik de behandeling van het tussenmagazijn als voorbereiding voor de expeditie. Vooral het tweede door mij genoemde onderwerp was toentertijd groot nieuws; niet het gehele bedrijfsleven stond echter te trappelen van verlangen om zich aan ponskaart-toepassingen te wagen hetgeen nogal frustrerend was voor vooruitstrevende vakgenoten.

Een jong literaat schreef eens een pil van een roman met de titel 'Zo zijn de mensen' welke hij ter recensie aan een befaamd criticus toezond. Na verloop van tijd ontving hij het boek terug zonder één opmerking: slechts aan de titel had de recensent het woordje 'niet' toegevoegd. Aan dit verhaaltje moest ik denken toen ik de critiek van $\mathrm{H}$. W. C. Bordewijk op het werk van S. de Wolff 'Het economisch getij' las. De Wolff besluit namelijk zijn voorwoord met het citeren van een oud-joodse wijsheid: 'doet uw werk ook reeds vóór de rijpheid der dagen en gij zult uw loon ontvangen als de tijden rijp zijn'. Bordewijk vult dat citaat aan met de opmerking dat dit loon niet alleen van de rijpheid der tijden maar vooral van de rijpheid van het werk zal afhangen. Ik wil, noch kan mij een oordeel aanmatigen over de in deze aanvulling verscholen kritiek maar vermeld deze slechts omdat ze daarna door Bordewijk in een boekbespreking van een voor het MAB ongebruikelijke omvang wordt geëxpliciteerd. Deze is zó omvangrijk dat beter van een artikel zou kunnen worden gesproken; het moest uitzonderingswijze met een kleine letter en minder wit tussen de regels worden gedrukt.

september 1933

Het schrijverspaar Ir. B. A. de la Houssaye en Drs. G. L. Groeneveld, waarvan wij ook verleden jaar reeds artikelen met een statistische inslag tegenkwamen levert thans een bijdrage welke de betekenis van de Paretocurve voor het marktanalytisch onderzoek tot onderwerp heeft. In die tijd zijn beide auteurs werkzaam bij de P.T.T. en het wekt dan ook geen verbazing dat zij een en ander toelichten aan de hand van aantallen telefonische hoofdaansluitingen. Zoals bekend geeft de Pareto-curve inzicht in de inkomensverdeling over de bevolking binnen een bepaald gebied.

Over de wijze waarop de goederenbeweging behoort te worden gecontroleerd zijn altijd veel pennen in beweging geweest. In het bijzonder de veertiger 
jaren, de periode waarin men zich definitief losmaakte van hetgeen de grote voormannen, met name Sternheim, terzake hadden gepropageerd, hebben heel wat heftige polemieken aanschouwd. E. P. M. van Waes schrijft nu een uitdagend artikel en draagt heel wat argumenten aan waarom hij zich keert tegen de opvatting als zouden de chronologische in- en verkoopregisters moeten worden afgecheckt tenzij dit geschiedt om de algemene accuratesse der administratie vast te stellen. Hij wil de inkoopfacturen checken met de magazijn- en de crediteurenadministratie.

In de rubriek 'Uit het Buitenland' wordt aandacht geschonken aan het feit dat thans een tweejarige ervaring is opgedaan met de beschermde titel van 'Wirtschaftsprüfer'. Heeft deze aan de verwachtingen beantwoord? Het blijkt dat het merendeel van de verplichte controles opgedragen wordt aan de grote Treuhandgesellschaften; de tegenstelling tussen deze instellingen en de 'Einzelwirtschaftsprüfer' is, ondanks de samenwerking in het Institut geenszins verdwenen. Wel zijn wat, beide partijen bevredigende wijzigingen in de voorschriften en de regeling van het stemrecht aangebracht. Het liberale toelatingsbeleid bij de instelling van de beschermde titel zou een teveel aan beroepsgenoten hebben veroorzaakt en het ontbreekt bepaald niet aan voorstellen om verdere toeneming van het aantal erkende accountants tegen te gaan. Het Institut vindt het niet op de weg van de examencommissies te liggen om door de wijze van beoordeling de concurrentie in het beroep te beperken. De ook bij ons zo bekende Prof. Dr. E. Schmalenbach had terzake voorstellen gedaan. Het Institut zoekt liever in de richting van uitbreiding der verplichte controles. Al mag deze plicht intussen wel de aanleiding zijn geweest van de titelbescherming men meent toch zich in de toekomst niet uitsluitend op deze werkzaamheden te moeten richten. En dan volgen nog enkele sobere mededelingen:

Het accountantswezen werd in de laatste maanden 'gleichgeschaltet', het bestuur van het Verband Deutscher Bücherrevisoren kwam in handen van leden van de NSDAP en Stahlhelm, het Treuhandverband koos uit leden van NSDAP en DNF. Het Institut der Wirtschaftspriffer trad toe tot de Bund National-sozialistischer Deutscher Juristen en werd ingevolge opdracht van de regering gleichgeschaltet. Reeds eerder werd er voorgesteld een verdere toelating van accountants van joodse afkomst voorlopig te staken.

Op het Federatief examen van het 'Instituut' en de 'Organisatie' komt een vraagstuk voor dat betrekking heeft op de 'volledige controle van de administratie en van de balans en winst- en verliesrekening alsmede de ondertekening van de balans' van de N.V. Oliehandel Olha. Op het stramien van deze Olha voortbordurend zijn in de loop van de volgende jaren heel wat vraagstukken geredigeerd. Daartegenover staat een vraagstuk dat niet veel navolgers heeft opgeleverd en dat werd voorgelegd aan de studenten van de Nederlandsche Handelshoogeschool. Het betrof een investigation in verband met het verzoek tot uitstel van betaling.

Tom Manders zong eens 'Met mij kan je alle kanten uit'. In dat verband twee meningen om de crisis te bestrijden welke ik broederlijk vereend in 
het repertorium vond:

C. A. Klaasse in 'de Zakenwereld' meent dat de regering zich zal moeten realiseren, dat de uitvoering van overheidswerken een der weinige gebieden blijft, waarin de overheid daadwerkelijk de crisisbestrijding ter hand kan nemen waartegenover echter C. J. P. Zaalberg in 'de Ingenieur' als zijn mening geeft dat onze werkloosheid pas kan verminderen als wij op de wereldmarkt kunnen concurreren. Hij meent dan dat de grote werken, waarvan sommigen heil verwachten als katalysator voor het herstel van de bedrijvigheid de financiële uitputting van het land zullen versnellen en de loondaling tegenhouden. Het herstel moet komen van de kracht, die de bedrijven stuk voor stuk weten te ontwikkelen. 